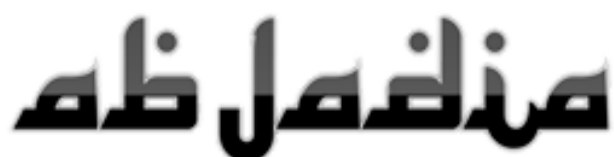

International Journal of Education

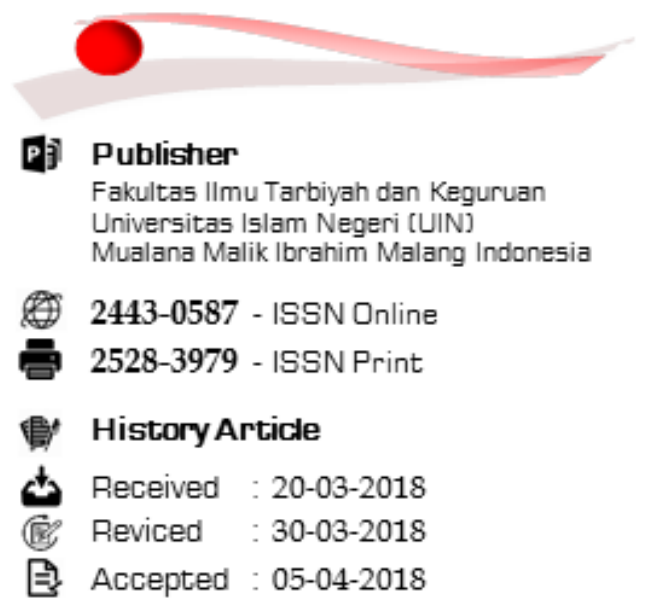

\subsection{0/abj. .3i1.5915}

http://ejournal.uin-malang.ac.id/index.php/ abjadia/article/view/5915

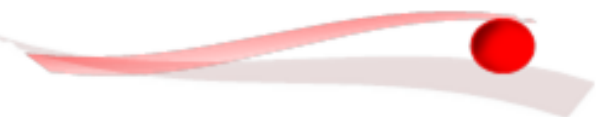

(2) Rosidin

I. Indonesia

(2) State Islamic Institute of Jember

(2) Handoko Ja'far

2. Indonesia

(3) College for Islamic Studies Ma'had Aly Al-Hikam Malang

Corresponding Author

(C) 081216332359

(9) mohammed.rosidin@gmail.com

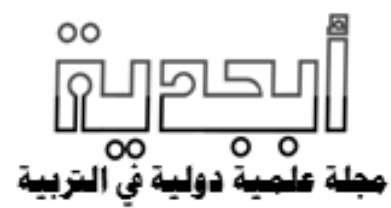

Rosidin, Handoko Ja'far

Indonesia

\section{PHILOLOGICAL ANALYSIS ON NORMATIVE HISTORICAL PRACTICAL TERM RAHMAH IN QUR'AN}

\section{嘒”, Abstract}

The article philologically analyzes the term rahmah through four data sources. First, al-Qur'an that often mentioned the term rahmah 563 times in 422 verses. Second, the book Shahih Bukhari-Muslim that sets forth the socialization of the term rahmah from insider perspective on the teachings and normative examples of Muhammad. Third, the book Muhammad: His Life Based on the Earliest Sourcesby Martin Lings andThe Venture of Islam byMarshall Hodgson that summonses rahmah socialization from outsider perspective through the life of prophet and muslim. Fourth, the book Ihya' 'Ulum al-Din al-Ghazali and Toward a Global Civilization of Love and Toleranceby Fethullah Gulen that describes rahmah practice as a way of life for classic and contemporary sufi. By means of three stages philological analysis: Informationsocialization-transformation, there are three claims of this article. Information phase, normative definition of term rahmah is a universal affection addressed to all creatures in universe. Socialization phase, normative definition of term rahmah socialized thru the teaching and normative examples of prophet, who assigns rahmah as an identity of muslim whether they are in minority status nor majority one. Rahmah practice socialization strengthened by the life of prophet and Muslim with affection domination rather than hatred. In transformation phase, rahmah appeared asa classic and contemporary sufistic life style that actively spread affection to all creatures with no insight of girded exoteric status.

Rahmah, Normative, Historic, Applicative, Philology

Citation: Rosidin, \& Ja'far, H. (2018). Philological Analysis on Normative Historical Practical Term Rahmah in Qur'an. Abjadia: International Journal of Education, 3(1), 1-16. 


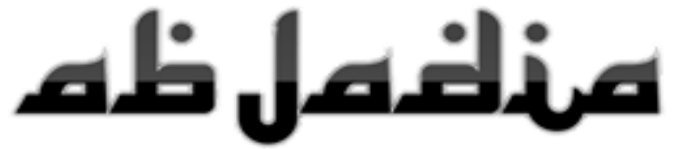

International Journal of Education

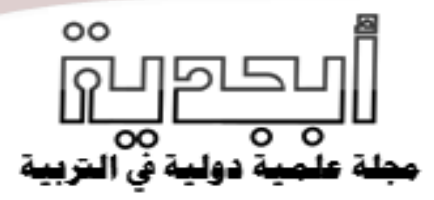

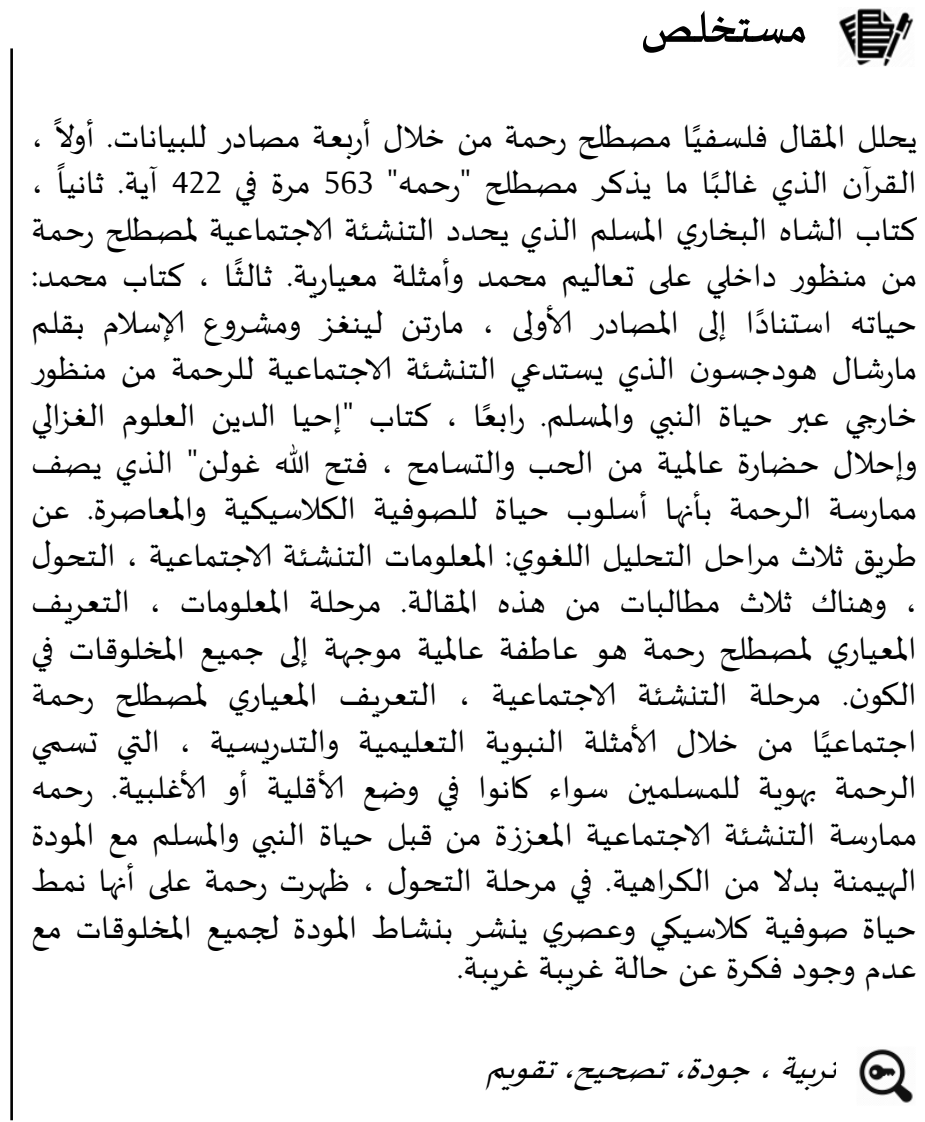

Q ن ن نوبية ، جودة، تصحيح، تقويم

\section{(C) INTRODUCTION}

Muslim claims al-Qur'anis the holliest religious text. It is Islam foundation and theirprimer source covers all life aspects; spiritual, legal, moral, economics, social, and even politic (Saeed, 2006) that leads to the birth of Islamic civilization through the alQur'an presence that contains 77.439 lexicons and 323.015 letter (Shihab, 2014). Confirmed by Nasr Hamid Abu Zaid -as it quoted by Luthfi- who takes Islam into consideration as a religion built on the text (haḍārah al-nāṣ). Whatever engaged with Islam, it will refer to the text. First text in Islam is al-Quran andHadith. Whilst, second one is Muslim comprehension toward first text. Furthermore, second text will give birthto the third one, a comprehended text of second one and so forth (Luthfi, 2016).

Through an investigation on Arab-Islam thought formulation,Al-Jabiri proved the text sigfinicance in Islamic civilization, and came to conclusion that science in ArabIslam based on dominant thought action, that is text based epistemology (bayāni) with the pointis a comparison between 'branch' and 'root' via certain correspondence. For instance, analogy mechanism (qiyas) by fiqh expert; deduction by theologian, or similes (tasybih) by rhetorician (al-Jabri, 2011). 
Though that same text to study, but it differs in meaning. The consequence is that all time Islam history, found so many different intrepretations on al-Qur'an and Hadith with an implication to differences in jurisprudence (fiqh), teology, philosophy, and politics that claim based on religion text interpretation.Sometimes this difference not only arises the rivality, but also triggers the war among Muslims (Nasr, 2003).

Text argumentation also flavors the conflict among religion. Mun'im Sirry identified three attitudes al-Qur'an toward non-Muslim. First, non-confrontative verses persuasively provide disbeliever with the freedom not to believe al-Qur'an teaching. Second, confrontative verses confirm the violance and even war as a self defence both individually and collectively. Third, Agresive verses that coersively emphasizes Jihādas an religious obligation for Muslim. The context is that al-Qur'an cronologically recited, thusfew Muslim scholars view the verses applied nowdays is that agresive ones, that instructs the violance and unconditionallywar (Sirry, 2017). Therefore, the purists claim that jihad versescanceled and obmitted all qur'anic teachings related to tolerance and appologies (El Fadl, 2005). This mindset then triggers violance acts in the name of religion, appearing the terminology vareity such as fundamentalist, puritanist, jihadist, radicalist, eextremist, and even terrorist (Nielsen, 2007). Factual sample is Bali I (Oktober 12, 2002) that according to doer action, Imam Samudra, it was Jihād fi sabilillah, due to come along with al-Qur'an instruction stated in al-Taubah [9]: 36 (Nugroho, 2016).

Acts of violence involving Muslims above confirms what Muhammad Abduhsaid "Islam is covered by Muslims" (al-Islāmmahjūu bi al-muslimīn). Yet, according to Esposito, Jihād model implemented only a handful of violent extremist organizations, such as al-Qaeda, while the majority of Muslims implement the model of non-violent Jihād (Esposito, 2002). But like the proverbial Indonesia, "Due to a drop of indigo, deterioration of milk." That is, just because of violence by Muslim minorities, destructive acts of love by the majority of Muslims.

The description above shows that the real problem lies in the human aspect, not doctrine. According to Omid Safi, in the world of the text, the most influential factor is human whoreads, interprets and deciphers the meaning of the text. In other words, the al-Qur'an teaching dissemination is accomplished through agent, human (Safi, 2003). The identical views expressed by Khaled El-Fadl which asserted that religion is a powerful force that has the ability to encourage adherents to the brink of hatred or engage in the glory of love. The potential power on all elements representing religion: the text and its history; creed and mythology; rituals and symbols. What comes out of this potential power, depending on the perception, attitude and behavior of the followers of the religion in order to show his religion with certain ways. On that basis, the author intends to philologicallyexamine the text of the al-Qur'an for supporting the ideas of global humanity nowdays, as stated in The Global Goals, agreementresult of 
193 world leaders on 25 September 2015, about 17 Global Goals that are expected to be achieved in 2030, the main points of the 16th, that is Peace and Justice Strong Institutions.

The text of the Qur'an on which philological analysis focuses is the verses that contain the term "mercy". The reason for choosing the terms of mercy as the focus of the study is the existence explicitly in chapteral-Anbiya'[21]: 107 that represents a vision and grand narrative that promoted Islam over the centuries,"li al-Rahmah'ālamīn", spreading the affection all over the world. Another reason is the terms of mercy always appear at the beginning of each letter -other than al-Taubah-, through editorial alRahmān (the Merciful) and al-Rahīm (the Most Merciful) in the phrase Bismillah. Even Khaled El-Fadl said al- Qur'an constantly offending values such as justice, honesty, compassion, goodness and truth seems like natural humaninnate (El-Fadl, 2001).

In broad outline, According to Gumbrecht there are two philology definitions. First, broadly it refers to the etymological meaning, which is "interested or fascinated by the words", so synonymous with the study of language. Second, the notion of a more specific and familiar, philology means treating or managing (curatorship) historical texts that refer exclusively to a written text (Gumbrecht, 2003). However, philological analysis in this paper refers to the meaning of the art of philology, which looked at differences in various manuscripts as a creative expression to understand the text, interpreting it, correct it and associate it with linguistic, literary, cultural, religious and political order of that time. Thus, the document is seen as a reflection of its time and its culture. This is called the modern philology (Baried, 1985).

In the study of modern Arabic linguistics, philology modern definition is consistent with the opinion of 'AbdShaburSyahin as quoted Luthfi- that defines philology (filulujiyya) as a science that not only studies the language in ancient texts, but also includes culture, history, traditions and literature (Luthfi, 2016). Moreover, the philology researchdevelopes its study on a deep understanding of the relevant various approaches (multi-disciplinary), that is still in the realm of philology study.With the up to date and relevant approach to the present problem, thus putting philology in accordance with the current development of the age and knowledge, so wider audiencesreap benefits from the role of philology (Istadiyantha, 2011).

Moving from that theoretical perspective, philological analysis of the terms rahmahin this paper utilizes four primary data sources in the form of a written text of a normative nature, historical and practical. First, the Qur'an states the terms rahmah 563 times in 422 verses as normative information.Second, the six books of main hadith (Kutub al-Sittah) asa historical sosialization of rahmahfrom insider's perspective through words, deeds and statutes of the Prophet Muhammad. Third, the book, "Muhammad: His Life Based on the Erliest Sources" Martin Lings and "The 
Venture of Islam" by Marshall Hodgson as historical socialization of rahmah of an outsider's perspective through the history of the life of the Prophet and Muslims. Fourth, "Ihya'Ulum al-Dīn" Al-Ghazali and "Toward a Global Civilization of Love and Tolerance" FethullahGulen work as the practical application of rahmah was done by the classical sufi and contemporary one.

Thus, there are three levels of philological analysis applied in this paper. First, the level of information that explores the meaning of rahmah normatively based on alQur'an and Hadith and their interpretation and commentary. Second, the degree of socialization of rahmah historically based prophetic saying and normative teaching of Muhammad and Islamic civilization history written by the insider (Muslim) and the outsider (non-Muslim). Third, the transformation ofrahmah on the practice life of the classical sufi and contemporary one.

\section{¡ịj DISCUSSIONS}

\section{Philological Analysis of Normative Information Phase}

Referring to the Dwight's proposal on the philosophy of language classification, the Arabic word derived from the Semitic language family, belonging to the language change systematically (inflected), structure (grammatical) and is still in use (living) in a conversation in the world (Dwight, 1860). Moreover, all the Semitic languages (Arabic, Hebrew, and Syriac) are a single root form consisting of three letters. This rule is also applied to the term rahmah rooted three-letter word, ra'-ha'-mim, then its shape systematically varies appropriate to applied grammar.

According to the search results of al-Baqi, al-Qur'an mentions the word rahmah and its derivation 563 times in 422 verses, detailed 292 verses of Meccan and 130 verse of Madaniyyah (Software Zekr). There are 31 forms of editorial in outline form: fi'il madhi (past tense), fi'il mudhari' (present and future tense), fi'il amar (command verb), mashdar (verba-nomina), isim fa'il (subject) and shighat mubalaghah (superlative). Whilst, according to the research result of Wensinck and Mensing, there are 12 word forms of rahmah in Kutub al-Sittah, Musnad al-Darimi, al-Muwaththa' and Musnad Aḥmad, i e: raḥima, raḥḥama, taraḥhama, tarāḥama, istarḥama, raḥimun-arḥām, ruḥmun, rahīmun-ruhamā'-raḥīmātun, raḥmah, rạ̣mān, raḥamūt,arḥam (Mensing, 1943).

Based on a review of linguistic, Ibn Faris said that the patron of letters ra' -ha'mim shows the meaning gentleness, love and affection (Faris, 2002). This meaning is also expressed in the dictionary of Ibn Manzhur; Lisān al-'Arab.. Related to its use in the Qur'an, al-Damaghani identified 14 meanings of term rahmah: Islam, rain, heaven, prophetic, favors, Quran, sustenance, aid, health, love, faith, taufiq, Prophet Isa and Prophet Muhammad. Furthermore, rahmah means as love contained in Q.S. al-Hadid [57]: 27 and al-Fath [48]:29 (al-Damaghani, 1996). Al-Ashfahani stated that the term 
rahmah comes from a word root of rahima meaning mother's womb. While, its meaning is a love that demands ihsān (best attitude) toward the blessed. If rahmah derived from Allah, then it means giving pleasure and grace; whereas if rahmah derived from humans, then it means love and gentleness (al-Ashfahani, 2003).

The definitive explanation above provides the normative information about the meaning of term rahmah coverage. First, etymologically it means affection. Second, in the connotation of the divinity, rahmah means love of Allah that has an implication for human compassion. Third, in the connotation of human, the term means directly human affection.

Affection nuance appears in the first verse consist of term derivation, rahmah, $\mathrm{i}$ e: al-Marhamah, in Q.S. al-Balad [90]: 17, Then will he be of those who believe, and enjoin patience, (constancy, and self-restraint), and enjoin deeds of kindness and compassion.

Explicitly, the above verse confirms that one of the characteristics of Muslims is linked intestate the mutual affection. Due to the editorial verse does not mention the object of affection, then the rules of interpretation applied in that the object tends something general. Thus, the object of affection is referred to in this verse is universal, as it was written the three following interpretation: According to the Tafsir al-Jalalayn, al-marhamah means compassion to creatures (al-rahma 'ala al-khalq) (al-Suyuthi, 1997). This interpretation is supported by the history of the Hadith of Ibn 'Abbas RA, that the meaning of al-marhamah is compassion for all mankind rahmah al-nas kullihim) (alSuyuthi, 1997). In Tafsir Tanwir al-Miqbas, al-marhamah means compassion to the needy and poor (Abbas, 2000).

Model of universal compassion is gaining legitimacy in many Hadith. First, the Prophet ordered the Muslims in order to be universal compassion for all beings on earth. The Prophet SAW said, "Love the creatures on earth, being in heaven will undoubtedly love you" (Transmitted by al-Tirmidhi). Second, the Prophet kissed his grandson, al-Hasan ibn 'Ali RA, when it was with al-Aqra' ibn Habis al-Tamimi. Then al-Aqra 'commented, "I have ten children, but I do not kiss nobody". Then the Prophet said, "Whoever does not love, then he would not be loved" (Transmitted by al-Bukhari). Third, the Prophet said, "Allah will not care for anyone who does not love mankind" (Transmitted by al-Bukhari). Fourth, the Prophet said, "I am not sent as a curser, but I was sent as a love spreader" (Transmitted by al-Bukhari). Fifth, the Prophet SAW said, "I was sent as a mercy to the worlds" (Transmitted by Abu Dawud).

These universal teachings of love get even stronger as the decline of chapter alAnbiya '[21]: 107, We sent thee not, but as a Mercy for all creatures.

Tafsir al-Jalalayn interprets the term al-'alamin (all creatures) in the above verse as the object of affection which includes mankind and the jinn. The same interpretation 
is also contained in the Tanwir al-Miqbas. Although both of these interpretations only on limit human and jinn who believe in Prophet Muhammad. More inclusive interpretation of al-Mawardi who considered that the term al-'alamin includes two senses. First, people who believe. Second, who are the believers and the infidels. In broader interpretation, Ibn 'Ashur asserted that this verse includes all living beings, animals included. For example, Islam forbids animals torture, even a hunting animals for pleasure. Rahmah related to non-Muslims, Ibn 'Ashur gave the example of the plight of non-Muslims under the auspices of the rule of Muslims, the ahl al-dhimma. They are not forced to come out of religion and are treated fairly in the eyes of the law.

The universal affection comes along with the results of the thematic interpretation study that al-Qur'an calls Muslims to turn on an ongoing basis of respect for the concept of universal humanity. Al-Qur'an informs that Allah has glorified humanity (Chapter Al-Isra '[17]: 70). The form is to realize that God created the diversity of human beings, and realize the interrelatedness of costly disputes among human beings whose cultures are diverse (Chapter Al-Hujurat [49]: 13). Therefore, alQur'an prohibits the crimes against humanity through an ethnic war and expulsion from the homeland, just because it's different from the religious beliefs of the majority (Chapter Al-Mumtahanah [60]: 8-9) (Hanafi, 2010).

In addition to the universal affection, the Qur'an also emphasizes internal affection Muslims. For example, Q.S. Ali 'Imran [3]: 159, It is part of the Mercy of Allah that thou dost deal gently with them Wert thou severe or harsh-hearted, they would have broken away from about thee: so pass over (Their faults), and ask for (Allah's) forgiveness for them; and consult them in affairs (of moment). This verse also becomes an example of divine love that has implications for human compassion. Internal affection is also reinforced by Q.S. al-Tawbah [9]: 128, "Now hath come unto you a Messenger from amongst yourselves: it grieves him that ye should perish: ardently anxious is he over you: to the Believers is he most kind and merciful".

The Prophet ever made illustrations related internal affection Muslims: "The likeness of the believers in love, affection and gentleness, like a body. If one of body member feels pain, then another limb feels the fever and it could not sleep "(Transmitted by Muslim). Prophet also criticized Muslims who do not behave compassion to fellow Muslims, through the prophetic saying, "If anyone does not love our juniors, and do not know our rights of seniors, then he's not one of us" (Transmitted by Abu Dawud).

From this it can be understood that the term rahmah and its derivatives in alQur'an has two connotations meaning of compassion. First, universal compassion that is generally legitimized by the verses of Meccan, like Q.S. al-Anbiya '[21]: 107. Second, 
the internal affection of Muslims who generally legitimized by passages Madaniyyah, like Q.S. al-Tawbah [9]: 61.

The problem is when the verses of Makkiyyah (Meccan) and the Madaniyah on affection interpreted by chronology downs through the verse-mansukh nasikh method. That is, the verses of Meccan that emphasizes universal compassion defeated by Madaniyyah verses that emphasize the internal affection. For example, Q.S. al-Tawbah [9]: 5, which was given the name, 'Verse of the Sword' (ayat al-saif), "And when the sacred months have passed, then kill the polytheists wherever you find them and capture them." The historical context of this verse is a war between Muslims and the infidels of Mecca in the 9th $\mathrm{H}$ and thematic context also about the war. However, this verse taken out of historical context and the thematic one and even claimed to have been established as law among Muslims with non-Muslims in every place, time and circumstances. Therefore, although the paragraph is deemed contrast to the more than two hundred other verses, which are all calling on dialogue, religious freedom, forgiveness, peace and patience. However, based on the method nāsikh-mansūkh, the majority of commentators concluded that Q.S. al-Tawbah [9]: 5 was revealed at the end of the life of the Prophet, have removed every verse 'as opposed to' revealed before, as Q.S. al-Ma'idah [5]: 13 "But pardon them and over look (their misdeed). Indeed, Allah loves the doer of good" and Q.S. al-Mu'minun [23]: 96, "Rapel by (means of) what is best, their (evil)". Moreover, a number of Hadith that legitimate the coexistence agreements multi-cultural also considered deleted (mansūkh). For example, 'Constitution of Medina' Hadith (shahifah al-Madinah), which states that Muslims and Jews form one nation (ummah) in which both the people have their own religion (Auda, 2008).

The consequent is that applied affection is an internal affection of Muslims only, while the universal love among mankind is no longer valid. Moreover there is a verse that seems to legitimize such behavior, for example Q.S. al-Fath [48]: 29, "Muhammad is the messenger of Allah; and those who are with him are strong against Unbelievers, (but) compassionate amongst each other". This is what the authors refer to as love discriminatory, ie being compassion to fellow Muslims and to be harsh to the nonMuslim community. At the extreme level, this discriminatory model of compassion transformed into a dangerous doctrine. For example, based on the doctrine of al-walā ' wa al-barā' (friendship and enmity), Abd al-Wahhab (funding father of Wahabism) stressed that Muslims should not be friends, allies or imitating the non-Muslims. Furthermore, a Muslim hostility to non-Muslims should be visible and unequivocal. The factual sample is that Muslims are prohibited from greeting the non-Muslims (El Fadl, 2005).

Indeed, the common thread of the above problems is an attribute seen in monodimensi, such as war and peace. In fact, if it is seen as a multidimensional 
attributes, then the arguments that seemed to contradict one another. Actually, it is not so when seen and read in the context of different. It implies the arguments that seem contrary to deconciliation (al-jam'u) in a new context (Auda, 2008). For example, in a state of "peace" as in Indonesia, the emphasis is universal among human affection; while in a state of "war" as in Palestine, the emphasis is on internal affection Muslims. This is what the authors refer to as contextual affection, that affection is applied in accordance with the context of the circumstances.

There are three conclusions of the philological analysis of normative information phase on the term rahmah and its derivatives in the Qur'an, hadith and interpretation of al-Qur'an. First, rahmah as an universal compassion, addressed to all beings, even animals, irrespective of carried status, while rahmah as an internal affection, addressed to fellow Muslims only. Second, the monodimensi mindset in understanding the verses of al-Qur'an that is based on the method nāsikh-mansūkh implies the internal affection superior and the universal compassion denial, thus forming the discriminative affection, ie being affectionate with Muslims and being hard to non-Muslim. Third, the multidimensional paradigm in understanding the verses of al-Qur'an that is based on periodization Meccan-Madaniyyah, has implications for the application of contextual affection, which emphasizes the universal compassion in the condition of "peace" and stressed internal affection in a state of "war".

\section{Philological Analysis of Historical Socialisation Stage}

Universal compassion and internally disseminated by the Prophet and Muslims, as embodied in the Kutub al-Sittah and the history of Islamic civilization. The orientation of affection can be tracked on five core teachings of Islam called maqāshid al-Sharia (the main objective of Islamic law), that is the maintenance of religion, mindbody, mind, family and possessions. In the view of Islam, the fifth is a primary need of mankind.

The examples of affection in the context of the maintenance of religion is religious freedom, as defined in Surat al-Baqarah [2]: 256 by the editorial, "Let there be no compulsion in religion". Tafsir al-Durr al-Mantsur identified a number of hadith that upheld a ban on forcing others into the Islamic religion. For example, a history of Ibn 'Abbas that this verse was revealed regarding the man named Ansar al-Hushain. He has two children who are Christians, while he himself is a Muslim. Then he was going to ask permission from the Prophet to be allowed to force her two children to convert to Islam. Then the verse came down. On another occasion, the Prophet also shows respect for non-Muslims. For example, when a funeral procession passed in front of the Prophet, he immediately stood up. Then no one told him that it was the body of the Jewish. Then the Prophet SAW said,"Is not he too human?" (Transmitted by al-Bukhari). 
In the history of Islam known as ahl al-dhimma term that refers to the nonMuslim people who live under Muslim government. They were given the honor religious tolerance, on condition of paying taxes (jizya). Marshall Hodgson stated that the Jews and Christians in Medina, was allowed to remain faithful to their religion, as dhimmis, those who are protected (Hodgson, 1974). Karen Amstrong confirmed that the non-Muslim people are not forced (by the Muslim ruler) to switch to Islam. Jews, Christians and Zoroastrians become dhimmis were not to be attacked just like that (Armstrong, 2002). In fact, according to Philip Hitti, dhimmis allowed to apply their own religious laws, as prescribed by their religious leaders (Hitti, 1989). For example, the Ottomans, as earlier Islamic dynasties, giving an autonomy to the people of nonMuslims in their internal life, both in terms of social, religious or social, which are governed by their own religious institutions (Lapidus, 2002).

If contextualize the present time, the attitude of the Prophet and Muslims above show affection to people in the form of non-Muslim religious tolerance. On the one hand they are respected as human beings, and on the other side of their religious beliefs are also respected.

In the context of the maintenance of body and soul, an example of affection is forbidden to kill non-Muslims (ahl al-dhimma). The Prophet Muhammad once said,"Whoever kills a person of ahl al-dhimma, then she will not smell heaven; and indeed it already smelled the smell of paradise (distance) travels seventy years "(Transmitted by al-Nasa'i). Related to war toward non-Muslims, the Qur'an has made significant changes related to the norms of warfare. For example, aggression is no longer considered as a way of worship; encourage Muslims to make peace when the enemy surrender or are likely to want peace; Muslims should not kill the prisoner (Saeed, 2008). The factual evidence is at the time of the conquest of Makkah (Fath alMakkah), the people of Makkah (non-Muslim people) who have for years been hostile to Muslims, it was treated with kindness and forgiveness (Hitti, 1989).

Based on historical records, it had made 80 military expeditions and only 27 expedition led by the Prophet with only a few expeditions that accompanied the war. However, it should be understood that the war happened during the Prophetic era for the 23 years, it only claimed around 1,018 lives, with details of 259 victims of the Muslims and non-Muslims 759 victims. This number is very small for a revolution by which the Prophet Muhammad in comparation with the Russian revolution in 1917 which killed up to 13 million lives; such as the revolution in France that claimed thousands of lives (Khan, 2005).

On that basis, Muslims are strictly forbidden to kill non-Muslims without any reasons that justified by Islamic law, such as the events of 9/11 that killed the victim 
4000-6000 from around 30 countries was believed to be carried out by the Al-Qaeda organization under the leadership of Osman bin Laden (Gupta, 2002).

The examples of affection in the context of the reason maintenance are the prophetic saying, "Seeking knowledge is obligatory for every Muslim" (Reported by Ibnu Majah) and his words, "Words of wisdom are the believer lost things, then when he finds it, he is entitled have it "( Transmitted by Tirmidhi). Two both Hadith show that science is inclusive and universal, without being restricted by the religious status.

Forexample, the intellectual movement characterized by the translation project of literary works of Persian, Sanskrit, Syrian and Greek into Arabic. Thus, Muslims became the heir of the older and cultured civilization of nations; and Muslims in Spain and Sicily deflected back to Europe and eventually gave the birth of the European Renaissance (Hitti, 1989). In this movement, the non-Muslim people (ahl al-dhimmah) participated by translating classical texts of philosophy and medical Hellenistic of Greek and Syiriac into Arabic (Armstrong, 2002). In addition, the non-Muslim community, like the Sabeans, Christians and Zoroastrians, participated teaching the Muslim students by using Arabic, as occurred during the reign of al-Ma'mun (Hodgson, 1974). On the other hand, Islamic universities which also teaches mathematics, astronomy, philosophy and medicine, has attracted foreign students, Christianity and Islam, so that they contribute to making Cordova as the intellectual center of the world (Hitti, 1973).

Thus, a form of affection related to reason maintenance and accommodation is the facilitation of academic activities given to Muslims and non-Muslims in order to master the science and technology that allows for the realization of civilization of a nation or state. Therefore, student exchange program, collaborative research by various scientific forums involving the Muslim participants and non-Muslim ones is the latest example of compassion associated reason maintenance.

An affection example in the context of the maintenance of the family was an example set by the Prophet. A testimony submitted his loyal servant, Anas ibn Malik: "I have never seen anyone more loving family than the Messenger" (Transmitted by Muslim). In a broader context, the Prophet united all the tribes in Medina (Muslim and non-Muslim) through the Charter of Medina, and united in friendship between Muslims, the Emigrants from Mecca by the Ansar of Medina (Hodgson, 1974). The form is any of the Ansar asked to be the host for the emigrants who at that time amounted to 200 people (Hitti, 1973). This is the first obligation of the Muslims that is to build a community (ummah) which is based on the practice of compassion in the form of share (Armstrong, 2002). From here, the fraternity is no longer blood based, but religion. Moreover, all who live in this community, regardless of tribal affiliations and loyalty to the old, now become brothers (Hitti, 1989). Thus, the fraternity became broader, that of 
brotherhood bound by blood or religion, became a brotherhood bound by the "homeland" or nation.

Based on the above description, the actual shape of love in the context of family maintenance can be realized via three models of fraternity, i e: Ukhuwwah Islamiyyah (brotherhood of Muslims), Ukhuwwah Wathaniyyah (brotherhood among fellow citizens) and Ukhuwwah Basyariyyah (brotherhood human race).

The example of affection in the context of the maintenance of the property is the words and deeds of the Prophet that emphasize the generosity to those who are in need. Like the words of the Prophet: "Fear of hell, though only with (charity) a piece of palm" (Transmitted by al-Bukhari). Another popular saying is, "The upper hand (giver), better than the hand below the (receiver)". (Transmitted by al-Bukhari). 'Aisha testified about the Prophet Muhammad: "I never saw Rasulullah SAW depute his Sadaqah to others, but he himself who handed shadaqah it into the hands of those who beg". (Transmitted by Ibn Majah). According to Philip Hitti, Islamic teachings on the treatment of slaves, orphans and strangers (traveler) are the most humane conditions in Islamic law (Hitti, 1989).

Both Muslims and non-Muslims alike burdened with the obligation to share. Muslims are obliged to pay zakat, while people of non-Muslims (dhimmi) must issue a tax (jizya). This policy eventually led to tolerance among religions for centuries (Endress, 2002). Furthermore, zakat and tax are distributed for the public interest and the needs of the poor and the wayfarer (ibn al-sabil), and so on (Hodgson, 1974).

As a result, the latest love in the context of the maintenance of property are acts of philanthropy directed to those who are in need, especially in order to realize a global goal on the first point and the second, that is no poverty (poverty reduction) and no hunger (eliminating the hunger ) caused social injustice.

Analysis of historical socialization writers conclude with the view of Karen Armstrong that Islam has always kept the idea of social justice, equality, tolerance and compassion practices as the vanguard Muslims for centuries. Though, Muslims are not always able to meet these ideals, and often find them difficult to realize in the social and political institutions. However, the struggle for the realization of those ideals has been becoming a major boost of the spiritual Islam for centuries (Armstrong, 2002).

\section{Philological Analysis of Practical Transformation Phase}

Practice compassion consistently implemented in the life of the classical and contemporary sufi. Examples of the love practice of classical sufi told by al-Ghazali, who identified three contexts of affection, namely faith, morals and sharia. At the level of faith, al-Ghazali gave the example that early spiritual growth is not demanding 
proofs and arguments, but simply blindly (al-Ghazali, 2011). This facilitates the general public who do not have to study the theological theories concerning their faith.

At the level of Sharia, al-Ghazali gave examples of various types of relief (rukhshah) in worship. For instance, waiver for traveler, fasting in Ramadan is not a compulsory (al-Ghazali, 2011). Indeed, Islam provides a double relief in terms of worship. First, worship is relatively light, such as a zakat profession, only $2.5 \%$ or $1 / 40$. Secondly, there are exemptions for people who can not, such as there is no obligation of zakat for women who are menstruating.

At the level of morality, the examples of affection are being praised to the neighbor, although his status is non-Muslims. For example, be gentle, to visit him when the neighbor was sick, congratulate when the neighbor is happy, forgive his mistakes, keep an eye on the house when he is not there, to be gentle with the neighbor's kids (alGhazali, 2011). Universally, al-Ghazali even asserted that however the diversity condition of mankind, they only need to be viewed with a kind of view, the view of love ('ayn al-rahmah) and looked at all men as servants of Allah (al-Ghazali, 2011). This is because when a Muslim is filled with compassion, then he can accept different opinions and beliefs of others, because he really understands the message of the religion that the differences of opinion among the people are a form of affection. This prophetic spirit confirms that love and compassion is a source of tolerance. While acts of intolerance, such as terrorism and radicalism, are the result of the loss of love and affection in the hearts of men (Muammar, 2003).

As examples of the practice of compassion by contemporary sufi, stated by Fethullah Gülen. Gülen paved the foundation of social, educational and religious movement that promotes the global version of Islam in the world. Scientists refer to this movement as "Gülen Movement" (Gülen Movement) (Sevindi, 2008). This movement offers a "way out" to Muslims based on the Islamic values in the face of the complexity of the demands of modern society. Starting from his native, Turkey, this movement spread quickly through the school in many countries, through cultural activities and the media, as well as through social work and dialogue that bring together people who belong to the Muslim Turkish diaspora in Europe, North America and Australia. All this shows that the influence of the Gülen movement was felt in almost all regions, in which Muslims resided, both as majority and minority (Gülen, 2009).

Globally, the Gülen movement is aimed at two objectives. First, invite Muslims to be aware that Islam teaches the need for a dialogue and Muslims are called to be agents and witnesses to the love of God is universal. Gülen invited in an effort to build a convincing argument that tolerance, love and compassion are values of genuine Islam, so Muslims should bring them to the modern world. Second, the Gülen Movement invites non-Muslim people to go beyond the attitude of prejudice, suspicion and half 
believe, in order to understand the true Islam. People who have a limited knowledge of Islamic values in the daily newspaper headlines, are likely to believe that Islam teaches terrorism, suicide attacks, oppressing women and hate those who are outside their community (Gülen, 2009).

Gülen considers that a genuine dialogue must be enforced in order to improve mutual understanding. In the end, Gülen promotes dialogue and tolerance among all strata of society, welcomed with a pleasure by people from all types of professions. At the end, Gülen even visited or received visits from religious leaders, leaders not only of citizens of Turkey, but also from around the world. Pope John Paul II at the Vatican, John O'Connor, bishop of New York, Leon Levy, former president of The AntiDefamation League which is representative of various world religions encountered by Gülen for dialogue (Gülen, 2009).

The inference to be drawn from this discussion is the sufi practice of internal compassion at the level of faith and worship, but it is universal in character level. In a broad scale, loving interaction between religious communities is realized through education and inter-religious dialogue involving Muslims and non-Muslims, in order to create a climate of peaceful relations, as a crucial prerequisite for the implementation of universal compassion.

\section{CONCLUSION}

Dynamics of terms rahmah and its derivatives as the representation of the compassion teachings in Islam, emphasizes universal and internal compassion that contextually applied. Teaching of affection is socialized in a historical journey of the Prophet and Muslims for centuries through five main objectives of Islamic law (maqāsid al-sharia), which maintains a religion, body and soul, mind, family and possessions. Furthermore, practiced consistently by classical and contemporary sufis through internal affection at the level of faith and worship, and universal compassion on the level of morality.

\section{BIBLIOGRAPHY}

al-Baqi, M.F.A. (2007). al-Mu'jam al-Mufahras li Alfazh al-Qur'an al-Karim. Kairo: Dar alHadits.

al-Ashfahani, R. (2003). Al-Mufradat fi Gharib al-Qur'an. Kairo: al-Maktabah alTawfiqiyyah.

al-Suyuthi, J. (1997). al-Durr al-Mantsur fi al-Ta'wil bi al-Mantsur.Vol. 10. Beirut: alMaktabah al-'Ashriyyah.

Armstrong, K. (2002).Islam: A Short History. New York: Modern Library. 
Auda, J. (2008). Maqasid al-Shariah as Philosophy of Islamic Law: a Systems Approach. London: The International Institute of Islamic Thought.

Baried, S.B. [dkk.] (1985). Pengantar Teori Filologi. Jakarta: Pusat Pembinaan dan Pengembangan Bahasa Departemen Pendidikan dan Kebudayaan.

al-Damaghani, M. (1996). al-Wujuh wa al-Nazha'ir: li Alfazh Kitabillah al-'Aziz.Vol. 1. Kairo: Al-Ahram.

Dwight, B.W. (1860). Modern Philology: Its Discoveries History and Influence. New York: A.S. Barnes \& Burr.

El-Fadl, K.M.A. (2001). And God Knows The Soldiers: The Authoritative and Authoritarian in Islamic Discourses. Lanham: University of American Press.

El-Fadl, K.M.A. (2005). The Great Theft: Wrestling Islam from the Extremists. New York: Perfect Bound.

Endress, G. (2002). Islam: An Historical Introduction, translated by Carole Hillenbrand. Edinburgh: Edinburgh University Press.

Esposito, J.L. (2002). Unholy War: Terror in the Name of Islam. Oxford: Oxford University Press.

al-Ghazali, A.(2011). Ihya' 'Ulum al-Din. Jeddah: Dar al-Minhaj.

Gülen, F. (2009). Toward A Global Civilization of Love and Tolerance. New Jersey: Tughra Books.

Gumbrecht, H.U. (2003). The Powers of Philology: Dynamics of Textual Scholarship. Chicago: University of Illinois Press.

Gupta, S. (2002). The Replication of Violence: Thoughts on International Terrorism after September 11th 2001. London: Pluto Press.

Hanafi, M.M. [et al]. (2010). Tafsir Tematik al-Qur'an: Spiritualitas dan Akhlak. Jakarta: Lajnah Pentashhihan Mushaf Al-Qur'an.

Hitti, P.K. (1989). History of the Arabs: From the Earliest Times to the Present. London: MacMillan.

Hitti, P.K. (1973). Capital Cities of Arab Islam. Minneapolis: University of Minnesota Press.

Hodgson, M.G.S. (1974). The Venture of Islam Conscience and History in a World Civilization: The Classical Age of Islam. Chicago: The University Of Chicago Press.

ibn 'Abbas, A. (2000). Tanwir al-Miqbas min Tafsir Ibni 'Abbas. Vol. 2. Beirut: Dar alKutub al-'Ilmiyyah.

ibn Faris, A.(2002). Mu'jam Maqayis al-Lughah.Vol. 2.np.: Ittihad al-Kitab al-'Arab.

ibn Manzhur, M. (n.d.). Lisan al-'Arab.Vol. 12. Beirut: Dar Shādir.

Istadiyantha. (2011). Problematika Penelitian Filologi: Tinjauan dari Perspektif Edisi Teks dan Kajian Teks. Dalam Manuskripta. Vol. 1. No. 2. 
al-Jabri, M.A. (2011). The Formation of Arab Reason: Text, Tradition and the Construction of Modernity in the Arab World. Translated by the Centre for Arab Unity Studies.In Contemporary Arab Scholarship in the Social Sciences. Vol 5. London: I.B.Tauris Publishers.

Khan, M.W. (2005). Muhammad: Nabi untuk Semua. Penerjemah Irwanti. Jakarta: Pustaka Alvabet.

Lapidus, I.M. (2002). A History of Islamic Societies. Cambridge: Cambridge University Press.

Luthfi, K.M. (2016). Kontekstualisasi Filologi dalam Teks-Teks Islam Nusantara. In Ibda': Jurnal Kebudayaan Islam. Vol. 14. No. 1. January-June.

al-Mahalli, J.andJ. al-Suyuthi. (1997). Tafsir al-Jalalain. Vol. 13. Beirut: al-Maktabah al'Ashriyyah.

Muammar, M.A. [dkk.] (2013). Studi Islam: Perspektif Insider/Outsider. Jogjakarta: IRCiSoD.

Nasr, S.H. (2003).Islam: Religion, History, and Civilization. London: HarperCollins Publishers.

Nielsen, J.S. (2007). The Discourse of 'Terrorism' between Violence, Justice and International Orderin Islamic Political Radicalism A European Perspective ed. Tahir Abbas. Edinburgh: Edinburgh University Press.

Nugroho, R.S. (2006).Jihad fi Sabilillah Menurut Pemikiran Imam Samudra dalam Buku Aku Melawan Teroris; Ditinjau dari Perspektif Dakwah. Skripsi Fakultas Dakwah IAN Walisongo Semarang In http://ibrary.walisongo.ac.id/digilib/download.php? id $=4482$ [cited 20 Februari 2017].

Saeed, A. (2006).Islamic Thought: An Introduction. New York: Routledge.

Saeed, A. (2008).The Qur'an: An Introduction.New York: Routledge.

Safi, O. [ed.]. (2003).Progressive Muslims: On Justice, Gender and Pluralism. Oxford: Oneworld Publications.

Sevindi, N. (2008).Contemporary Islamic Conversations. New York: State University of New York.

Shihab, M.Q. (2014).Wawasan al-Qur'an: Tafsir Tematik Atas Pelbagai Persoalan Umat. Bandung: Mizan.

Sirry, M. Kekerasan dalam Al-Qur'an Bukan Problem Interpretasi. In http://geotimes.co.id/kekerasan-dalam-al-quran-bukan-probleminterpretasi/\#gs.N8LKFsE [cited 20 Februari 2017].

Wensinck, A.J. and J.P. Mensing. (1943). Al-Mu'jam al-Mufahras li Alfazh al-Hadits alNabawi.Vol. 2. Leiden: Brill.

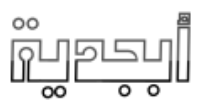

